\title{
歯周疾患患者の改良暫間固定治療法の 経過観察結果
}

\author{
神 戸洋子松 江一 郎 \\ 日本大学松戸歯学部保存歯周病学教室 \\ （主任 : 松江一郎教授） \\ (昭和 56 年 12 月 20 日受付)
}

\section{A Study on the Prognosis following Improvement Temporary Fixation of Periodontal Patients}

\author{
Yoko KAMBE and Ichiro MATSUE \\ Department of Periodontology \\ Nihon University School of Dentistry at Matsudo \\ (Director: Prof. Ichiro MATSUE)
}

The treatment of periodontal disease have to establish the system of periodontal therapy depend on the etiology and advance mechanism of periodontal disease. For the purpose of occlusal therapy, it is important to reevaluate the temporary fixation for treatment of the advance periodontal disease. Therefore, this study was designed to evaluate the prognosis of the periodontal treatment and the temporary fixation treatment, using the finding of the clinical examination and the standardized technique for radiography.

Of the periodontal patients who visited the Department of Periodontic Nihon University Dental Hospi-

\section{I. 緒言}

歯周疾患患者を治療するに際して, 歯周疾患の病因と 進行機構を考えた治療システムを確立する必要がある。 その治療システムでの進行した歯周炎の症例では, 治療 法の歯周外科手術を行うと, その手術前後に伴う歯の動 摇に対して, 安静と保定の目的で暫間固定法を行う必要 のある症例がある。 tal at Matsudo, 7 patients needed for temporary fixation following the periodontal treatment the progress following the temporary fixation were examined at a month, 3 months, and 6 months after the fixation comparing the condition of pre-fixation.

The data of the clinical examination report and the remodeling of alveolar bone observed by the standardized technique for radiography were applied for the examination.

The remodeling of alveolar bone was observed by the application of temporary fixation. The composits resin material used in this study was effective in temporary fixation until 6 months.

この研究は, 歯周外科処置後に暫間固定を必要とした 患者, 7 症例を対象とし, 金属と接着する KG (81-06) レジンを用いて暫間固定を行い，臨床検查用紙や規格 $\mathrm{X}$ 線写真などを用いて，この暫間固定法の経過観察評価を 行い, 歯周疾患処置と暫間固定法について若干の知見を 得た。 


\section{II. 研究方法}

\section{1. 研究対象及び材料}

日本大学松戸歯科附属病院に来院した歯周疾患患者の 中から，特に歯周外科処置後に暫間固定を必要とした患 者， 7 症例を対象とし，固定部位は上下䫟臼歯部とした (表 1)。

なお, 本研究に使用した器材, 器具は (表 2)。に示し た。

表 1 Subject and the diagnosis

\begin{tabular}{|c|c|c|c|c|}
\hline $\begin{array}{l}\text { patient } \\
*\end{array}$ & $\begin{array}{c}\text { sex } \\
\text { female }\end{array}$ & $\begin{array}{l}\text { age } \\
47\end{array}$ & $\begin{array}{c}\text { diagnosis } \\
\text { periodontitis }\end{array}$ & $\begin{array}{l}\text { region } \\
4-6\end{array}$ \\
\hline & & " & "I & $6-4$ \\
\hline & male & 43 & "I & $\|$ \\
\hline & female & 37 & "I & "I \\
\hline & male & 53 & "I & $7-4$ \\
\hline & female & 49 & $\|$ & $\|$ \\
\hline & male & 76 & "I & $5-4$ \\
\hline
\end{tabular}

表 2 Experimental materials

\footnotetext{
* K-G (81-06) resin

* 18-8Stainless steel, 0.25 or $0.30 \mathrm{~mm}$ wire

* Clinical examination report

* Modified method of SCHEI-WAERHAUG,

MATSUE measurement scale

* Stabilized appliance for radiography

* Color data system model
}

\section{2. 研究方法}

本研究に用いた暫間固定法は, A-splint 法, すなわち 内式暫間固定法である。

この方法は, 1951 年の $\mathrm{Obin}^{8)}$ 等のワイヤーとレジン を用いた方法以来, 現在改良法が考案され広く行われて いるが，この研究の方法は金属と接着する KG (81-06) レジンを用いて，暫閒固定を行った点にある。

この暫閒固定法の術式は次の通りである。

固定部位は主として, 第 1 小臼歯, 第 2 小囦歯, 第 1 大臼歯，及び第 2 大臼歯，4歯である。

固定を行う前に，あらかじめ対象者の口腔内を Brushing や Scaling を行い良好にしておく。

次に 18-8 ステンレスワイヤー $(0.25 \sim 0.3 \mathrm{~mm})$ をマ ンドトールに数回，巻きつけ繩状の固定用ワイヤーを作 製しておく。
通法に従い，ラバーダム防湿を行い，ステイムデント を歯間部に挿大し，歯閒空隙を確保する。これにより， レジン泥の流大による歯肉の損傷, 口腔清掃が不十分で 不潔になりやすいのを防ぐ(図1)。

次に暫閒固定用としての窩洞形成を行った。(アンダ ーカットを持つように MOD 窩洞に形成する。)

歯髄を避けて TMS ピンを植立する為のホール（2〜 $2.5 \mathrm{~mm}$ の深さ）を形成し，ピンをねじ込む。ピン植立 後, あらかじめ用意しておいたワイヤーをピンで絡めな がら窩洞内に沿うように（バンドプッシャーで）押え適 合させた (図 2)。

次に通法に従いエッチング，ボンデイングを行って $\mathrm{KG}$ (81-06) レジンを充垻後，その上にテインフォイル で圧接し，咬合面形成を行った (図 3)。

さらに，インデイケーターワックスと咬合紙によって 咬合調整を行った (図 4)。

そして咬合調整後，削合部位を研磨した（図 5)。（固 定法完了)

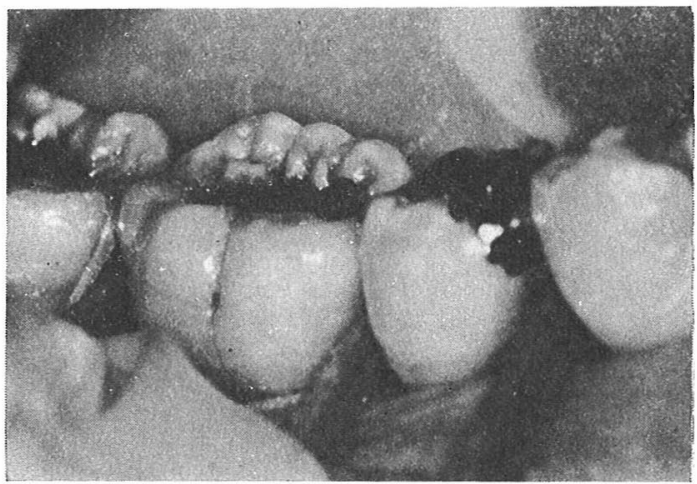

図 1 固定前の口腔内写真 部位 $\overline{7-4}$

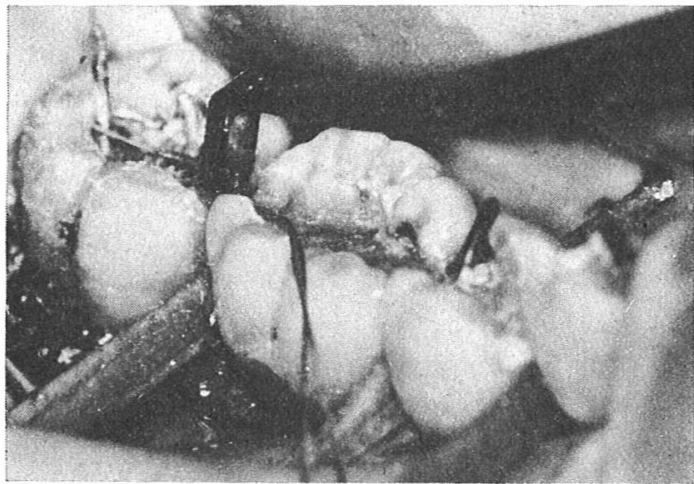

図 2 窩洞形成

MOD 窩洞形成後, TMS ピンを植立し，ワイヤーを 窩洞内に適合させている状態 


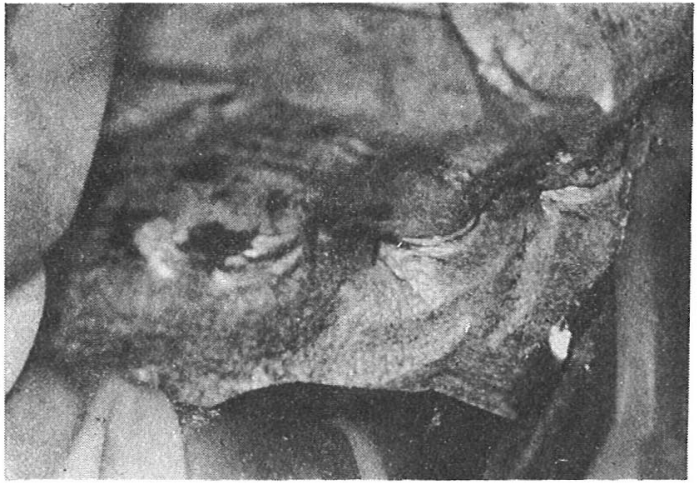

図 $3 \mathrm{KG}$ (81-06) レジンを窩洞内に充填し, そ の上をテインフォイルで圧接している状態

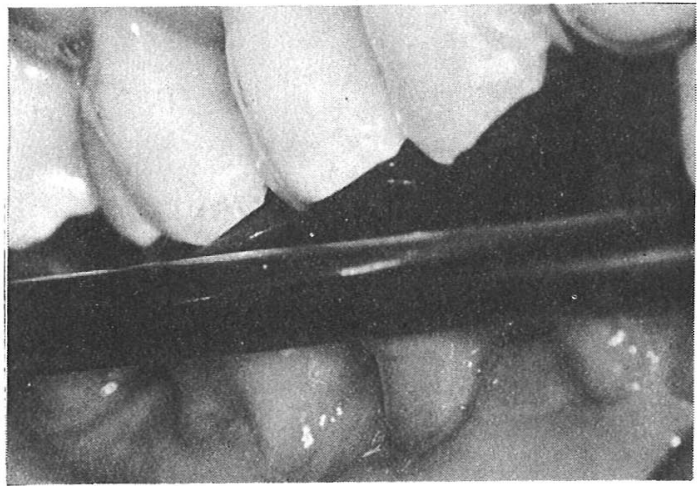

図 4 インディケーターワックスと咬合紙を重ね たものによって，咬合状態を診査し，咬合 調整を行なっている状態

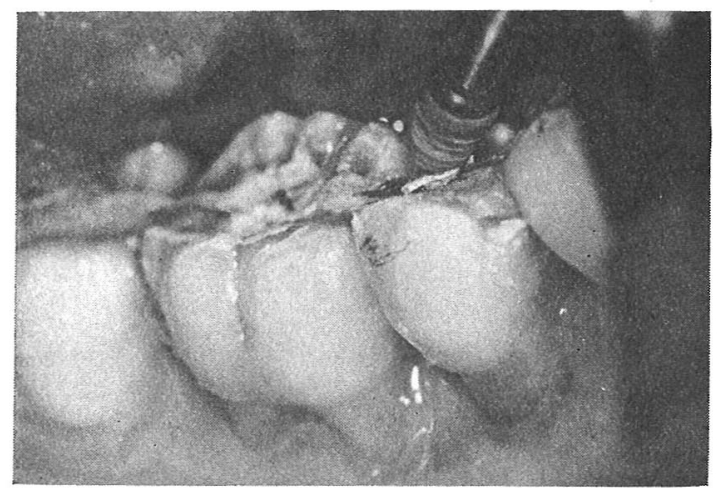

図 5 咬合調整を行い，削合部位を研磨してい る状態

\section{3. 暫間固定後の経過観察項目と期間}

経過観察期閒は固定前 (0) より固定後 6 力月間で次 の a), b), c), の項目について評価を行った。
a）臨床検査用紙による評価

b) Schei-Waerhaug 改良松江式スケールを用いての 規格X線写真による骨の remodeling に関する評価

c） b）を客観的評価する為にカラーデーターシステ ムモデルを用いての評価

\section{III. 研究成績}

a）暫間固定法の臨床所見の経過観察結果

表 3 に示寸臨床検查用紙を使用し, 各項目について診 查した結果, 固定前から固定後 6 力月の全観察期閒を通 しては，辺縁破折が固定後 1 力月に 1 症例, 3 力月に 2 症例みられた。

表 3

$\mathrm{S}$; subject

M; months after fixation

-; no case was found

$* ; 7$ patients, ***; 5 patients, $* * * ; 3$ patients,

\begin{tabular}{|c|c|c|c|c|}
\hline M & $0^{*}$ & $1^{*}$ & $3^{* *}$ & $6^{\text {wow }}$ \\
\hline \multicolumn{5}{|l|}{ A. gingiva and pulp } \\
\hline 1 hyperesthesia & - & - & - & - \\
\hline 2 cold water pain & - & - & - & - \\
\hline 3 percussion pain & - & - & - & - \\
\hline 4 spontaneus pain & - & - & - & - \\
\hline 5 hyperemia & - & - & - & - \\
\hline 6 inflammation & - & - & - & - \\
\hline 7 necrosis of the pulp & - & - & - & - \\
\hline 8 pulpectomy & - & - & - & - \\
\hline \multicolumn{5}{|l|}{ B. tooth condition } \\
\hline 1 discoloration & - & - & - & - \\
\hline 2 fracture & - & - & - & - \\
\hline 3 recurrent caries & - & - & - & - \\
\hline \multicolumn{5}{|l|}{ C. filling } \\
\hline 1 marginal fracture & - & 1 & 2 & - \\
\hline 2 body fracture & - & - & - & - \\
\hline 3 abrasion & - & - & - & - \\
\hline 4 rough of surface & - & - & - & - \\
\hline 5 marginal discoloration & - & - & - & - \\
\hline 6 falling & - & - & - & - \\
\hline
\end{tabular}


b）暫間固定法の規格 $\mathrm{X}$ 線写真を用いての固定前後の 歯槽骨の骨の remodeling の観察評価結果

固定前から固定後 6 カ月までの歯槽骨の高さを測定す る為に, Schei-wearhaug 改良松江式スケールを用いて， 近心歯間部歯槽骨 $(M)$, 遠心歯間部歯槽骨 (D), 根分岐 部歯槽骨 (F) についても測定した（図 $6 \mathrm{a} ， \mathrm{~b})$ 。その測 定結果注 4,5 , に示した。

$\mathrm{OPe}$ 後，暫間固定を行わなかった症例の測定結果（表 4)。

$\mathrm{OPe}$ 後，暫間固定を行った症例の測定結果である（表 $5)$ 。

表 5 をグラフ化したものを図 7 に示した。各歯周疾患 患者において固定前から固定後 6 力月における各部位の 近心歯間部歯槽骨 (M)。遠心歯間部歯槽骨 (D)。根分 岐部歯槽骨 (F) の合計に $\mathrm{M}+\mathrm{D}+\mathrm{F}$ ) を示したグラフ である (図 7)。

これらの表 5 , 図 7, から，この暫間固定法による歯 槽骨の remodeling については, 固定前に比較すると固 定後は 7 症例中, 1 症例を除き骨の remodeling が認め られた。

c） カラーデーターシステムモデルによる固定前後の 歯槽骨の remodeling の客観的評価結果

さらに我々は, この規格 X線写真による上記結果より 客観的評価する為にカラーデーターシステムモデルを用 いて骨の remodeling について検討した(図 8〜図 13)。

その結果, 規格X線写真の結果と同様に, 骨の remodeling が認められた。

MEASUREMENT OF ALVEOLAR BONE ABSORPTION

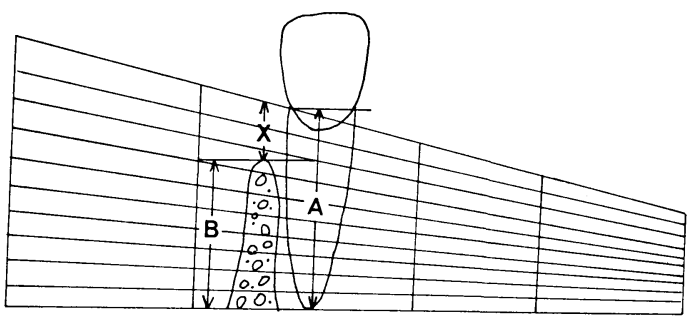

alveolar bone absorption $(X) \doteq \frac{A-B}{A} \times 10$

A: root length

B; remaining alveolar bone, margin

図 6 a. 前歯
MEASUREMENT OF ALVEOLAR BONE ABSORPTION

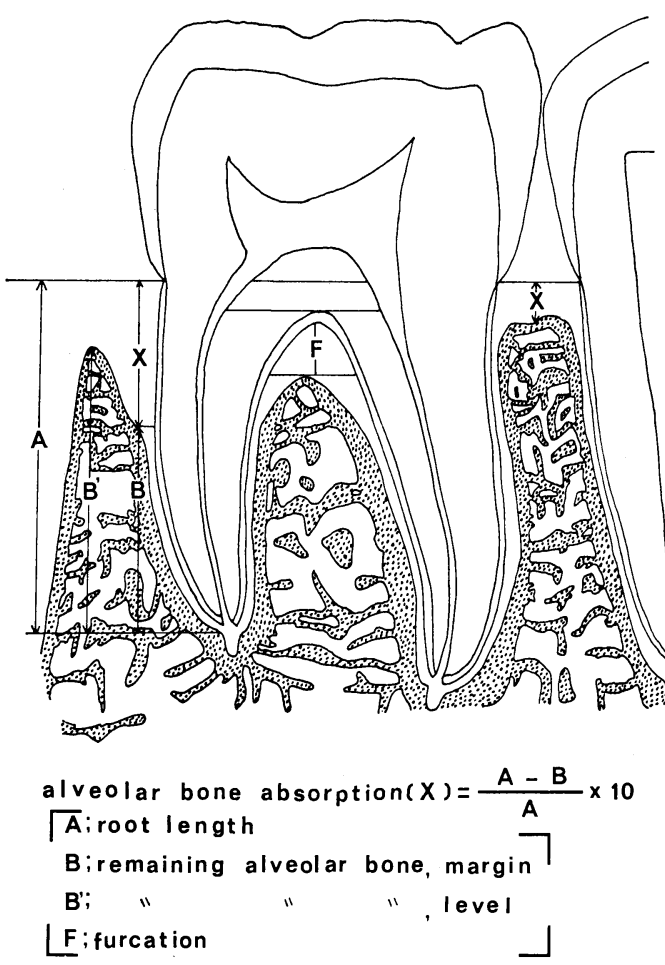

図 6 b. 白歯

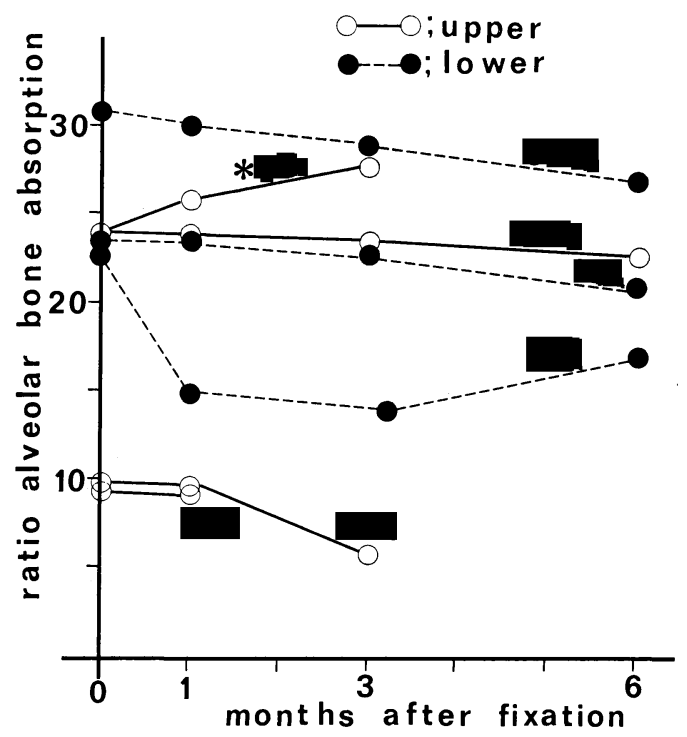

図 7 
表 4 対照側

\begin{tabular}{|c|c|c|c|c|c|c|c|c|c|c|c|c|c|}
\hline \multirow{3}{*}{$\mathbf{P}$} & \multirow{3}{*}{$\begin{array}{r}\mathrm{R} \\
\mathrm{M} \\
\end{array}$} & \multicolumn{12}{|c|}{ UPPER RIGHT } \\
\hline & & \multicolumn{3}{|c|}{7} & \multicolumn{3}{|c|}{6} & \multicolumn{3}{|c|}{5} & \multicolumn{3}{|c|}{4} \\
\hline & & $\mathrm{f}$ & d & $\mathbf{m}$ & $f$ & $d$ & $\mathrm{~m}$ & $f$ & $d$ & m & f & $d$ & $\mathrm{~m}$ \\
\hline & 0 & - & 3 & 3 & - & 5 & 2 & 一 & 2 & 2 & 一 & 2 & 2 \\
\hline & 1 & - & 3 & 3 & - & 5 & 3 & - & 2 & 2 & - & 2 & 2 \\
\hline & 3 & 一 & 2 & 3 & - & 4 & 3 & - & 2 & 2 & - & 2 & 2 \\
\hline & 6 & 一 & 2 & 3 & 一 & 4 & 2 & - & 2 & 2 & - & 2 & 2 \\
\hline & 0 & - & 2 & 3 & 3 & 4 & 3 & 一 & 2 & 2 & - & 2 & 3 \\
\hline & 1 & - & 2 & 3 & 2 & 5 & 3 & - & 2 & 2 & - & 2 & 3 \\
\hline & 3 & - & 2 & 3 & 2 & 4 & 4 & - & 2 & 2 & 一 & 2 & 2 \\
\hline & 6 & - & 2 & 3 & 2 & 4 & 4 & - & 2 & 2 & 一 & 2 & 2 \\
\hline & 0 & - & 1 & 1 & - & 2 & 1 & - & 1 & 1 & 一 & 1 & 1 \\
\hline & 1 & - & 1 & 1 & - & 2 & 2 & - & 1 & 1 & - & 1 & 1 \\
\hline & 3 & - & 1 & 1 & - & 2 & 2 & - & 1 & 1 & - & 1 & 1 \\
\hline & 6 & - & 1 & 1 & - & 1 & 1 & - & 1 & 1 & - & 1 & 1 \\
\hline & 0 & 一 & 3 & 3 & - & 3 & 3 & - & 2 & 2 & - & 2 & 3 \\
\hline & 1 & 一 & 3 & 3 & - & 3 & 3 & - & 2 & 2 & - & 2 & 3 \\
\hline & 3 & - & 3 & 2 & - & 3 & 3 & - & 2 & 2 & - & 2 & 3 \\
\hline & 6 & - & - & - & - & 3 & 2 & - & 2 & 2 & - & 2 & 2 \\
\hline
\end{tabular}

$\mathrm{P}$; patient

$\mathrm{R}$; region

$\mathrm{M}$; months after operation

\begin{tabular}{|c|c|c|c|c|c|c|c|c|c|c|c|c|c|}
\hline \multirow{3}{*}{$\mathrm{P}$} & \multirow{3}{*}{$\begin{array}{r}\mathrm{R} \\
\mathrm{M} \\
\end{array}$} & \multicolumn{12}{|c|}{ LOWER RIGHT } \\
\hline & & \multicolumn{3}{|c|}{7} & \multicolumn{3}{|c|}{6} & \multicolumn{3}{|c|}{5} & \multicolumn{3}{|c|}{4} \\
\hline & & f & $\mathrm{d}$ & $\mathrm{m}$ & $\mathrm{f}$ & $d$ & $\mathrm{~m}$ & $\mathrm{f}$ & d & $\mathrm{m}$ & $\mathrm{f}$ & d & $\mathrm{m}$ \\
\hline & 0 & - & 6 & 7 & 3 & 7 & 5 & - & 3 & 2 & - & 2 & 2 \\
\hline & 1 & - & 6 & 8 & 3 & 7 & 6 & 一 & 3 & 3 & - & 3 & 2 \\
\hline & 3 & - & 6 & 8 & 3 & 7 & 6 & - & 3 & 3 & - & 3 & 3 \\
\hline & 6 & - & - & 一 & 3 & 8 & 6 & - & 3 & 3 & - & 3 & 3 \\
\hline & 0 & - & 2 & 2 & - & 2 & 2 & - & 2 & 2 & - & 2 & 2 \\
\hline & 1 & - & 2 & 2 & 一 & 3 & 2 & - & 2 & 2 & - & 2 & 2 \\
\hline & 3 & - & 2 & 1 & - & 2 & 2 & - & 2 & 2 & - & 2 & 2 \\
\hline & 6 & - & 2 & 1 & - & 2 & 2 & - & 2 & 2 & - & 2 & 2 \\
\hline & 0 & - & 2 & 3 & - & 4 & 3 & - & 3 & 2 & - & 2 & 2 \\
\hline & 1 & - & 2 & 2 & - & 4 & 3 & - & 3 & 2 & - & 2 & 2 \\
\hline & 3 & - & 2 & 2 & - & 3 & 3 & - & 3 & 2 & - & 2 & 2 \\
\hline & 6 & - & 2 & 2 & - & 3 & 3 & - & 3 & 2 & - & 2 & 1 \\
\hline
\end{tabular}

f ; furcation

$\mathrm{m}$; interdental bone in the mesial side

$d$; interdental bone in the distal side

-; no case was found 
表 5 実験側

\begin{tabular}{|c|c|c|c|c|c|c|c|c|c|c|c|c|c|}
\hline \multirow{3}{*}{$\mathrm{P}$} & \multirow[b]{3}{*}{ M } & \multicolumn{12}{|c|}{ UPPER RIGHT } \\
\hline & & \multicolumn{3}{|c|}{7} & \multicolumn{3}{|c|}{6} & \multicolumn{3}{|c|}{5} & \multicolumn{3}{|c|}{4} \\
\hline & & f & d & $\mathrm{m}$ & f & d & $\mathrm{m}$ & $\mathrm{f}$ & d & $\mathrm{m}$ & $\mathrm{f}$ & $d$ & $\mathrm{~m}$ \\
\hline & 0 & - & - & - & - & 4 & 5 & - & 3 & 4 & - & 4 & 4 \\
\hline & 1 & - & - & - & - & 4 & 5 & - & 4 & 4 & - & 4 & 5 \\
\hline & 3 & - & - & - & - & 4 & 5 & - & 5 & 4 & - & 5 & 5 \\
\hline & 6 & - & - & - & - & - & - & - & - & - & - & - & - \\
\hline & 0 & - & - & - & - & 4 & 5 & - & 5 & 5 & - & 3 & 2 \\
\hline & 1 & - & - & - & - & 4 & 5 & - & 5 & 5 & - & 3 & 2 \\
\hline & 3 & 一 & - & - & - & 4 & 5 & - & 5 & 5 & - & 3 & 2 \\
\hline & 6 & - & - & - & - & 4 & 5 & - & 5 & 5 & - & 3 & 2 \\
\hline & 0 & - & - & - & 0 & 3 & 3 & - & 1 & 1 & - & 1 & 1 \\
\hline & 1 & - & - & - & 0 & 3 & 3 & - & 1 & 1 & - & 1 & 1 \\
\hline & 3 & - & - & - & 0 & 2 & 1 & - & 1 & 1 & - & 0 & 1 \\
\hline & 6 & - & - & - & - & - & - & - & 一 & - & - & - & - \\
\hline & 0 & - & - & - & - & 3 & 3 & - & 1 & 1 & - & 1 & 1 \\
\hline & 1 & - & - & - & - & 3 & 3 & - & 1 & 1 & - & 1 & 1 \\
\hline & 3 & - & - & - & - & - & - & - & - & - & - & - & - \\
\hline & 6 & - & - & - & - & - & - & - & - & - & - & - & - \\
\hline
\end{tabular}

$\mathrm{R}$; patient

$\mathrm{R}$; region

$M$; months after fixation

*; UPPER LEFT

\begin{tabular}{|c|c|c|c|c|c|c|c|c|c|c|c|c|c|}
\hline \multirow{3}{*}{$\mathrm{P}$} & \multirow[b]{3}{*}{ M } & \multicolumn{12}{|c|}{ LOWER RIGHT } \\
\hline & & & 7 & & \multicolumn{3}{|c|}{6} & \multicolumn{3}{|c|}{5} & \multicolumn{3}{|c|}{4} \\
\hline & & $\mathrm{f}$ & d & $\mathrm{m}$ & $\mathrm{f}$ & $d$ & $\mathrm{~m}$ & $\mathrm{f}$ & $\mathrm{d}$ & $\mathrm{m}$ & $\mathrm{f}$ & $\mathrm{d}$ & $\mathrm{m}$ \\
\hline & 0 & 2 & 2 & 4 & 2 & 2 & 2 & - & 3 & 2 & - & 2 & 2 \\
\hline & 1 & 0 & 1 & 2 & 1 & 2 & 2 & - & 2 & 1 & - & 2 & 2 \\
\hline & 3 & 0 & 1 & 1 & 1 & 2 & 2 & - & 2 & 1 & - & 2 & 2 \\
\hline & 6 & 0 & 1 & 2 & 2 & 2 & 2 & - & 2 & 2 & - & 2 & 2 \\
\hline & 0 & 0 & 1 & 1 & 1 & 2 & 4 & - & 7 & 8 & - & - & - \\
\hline & 1 & 0 & 1 & 1 & 1 & 2 & 4 & - & 7 & 8 & - & - & - \\
\hline & 3 & 0 & 1 & 1 & 1 & 2 & 3 & - & 7 & 8 & - & - & - \\
\hline & 6 & 0 & 1 & 1 & 1 & 2 & 3 & - & 6 & 7 & - & 4 & 4 \\
\hline & 0 & - & - & - & - & - & - & - & 9 & 8 & - & 7 & 7 \\
\hline & 1 & - & - & - & - & - & - & - & 8 & 8 & - & 7 & 7 \\
\hline & 3 & - & - & - & - & - & - & - & 8 & 7 & - & 7 & 7 \\
\hline & 6 & - & - & - & - & - & - & - & 7 & 7 & - & 6 & 7 \\
\hline
\end{tabular}

$\mathrm{f}$; furcation

$\mathrm{m}$; interdental bone in the mesial side

$\mathrm{d}$; interdental bone in the distal side

-; no case was found 


\section{経過観察結果}

今回, 研究を行った 7 症例の中から 1 症例について報 告する（図 8〜図13）。

本症例 右側第 1 小曰歯より第 2 大臼歯に咬合性外傷を伴う歯周 炎である。

固定前においては全顎にわたる辺縁歯槽骨に中等度以 上の吸收像を認めた。第 1 大白歯の根分岐部に而度の骨
欠損を認めた。第 2 小臼歯の近心骨頂部の吸収像を認め た（図 8,9）。

次に固定後 3 力月においては第 1 大臼歯の根分岐部に 著明な骨の再生 (remodeling) 像を認め, 第 2 小臼歯の 歯間部歯槽骨の再生（remodeling）像を認めた（図 10, 11)。

さらに固定後 6 カ月においては根分岐部と歯間部の歯 槽骨壮安定した状態が認められた（図 12,13 )。

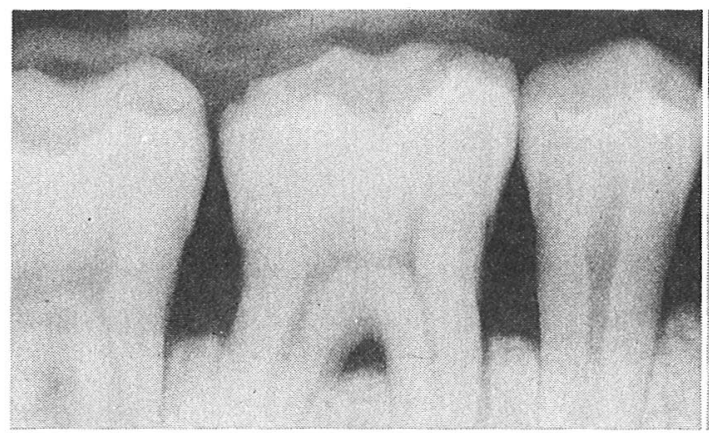

図 8 固定前の規格X線写真 部位 $\overline{7-4}$

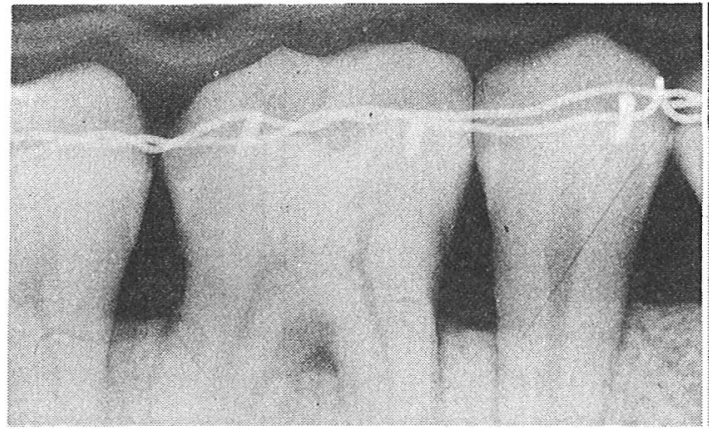

図 10 固定後 3 力月の規格 $\mathrm{X}$ 線写真

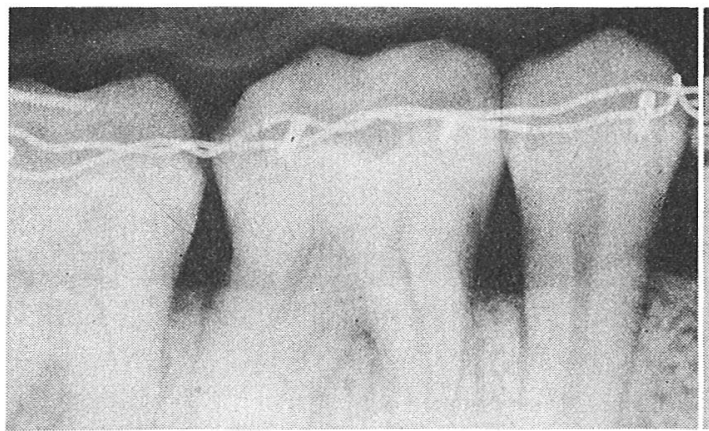

図 12 固定後 6 力月の規格 $X$ 線写真

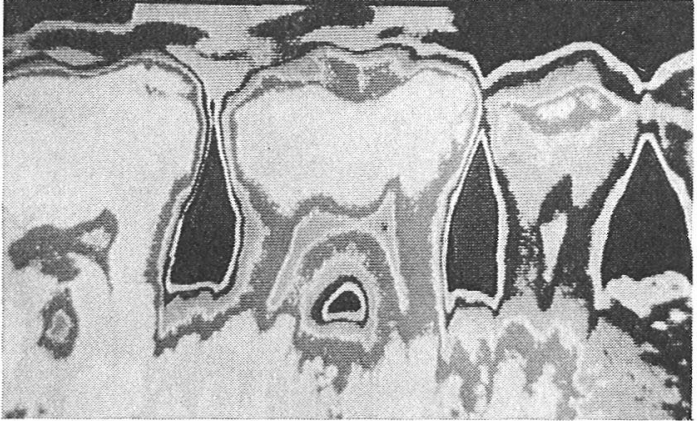

図 9 网 8 (固定前) のカラーデーター システムによる評価

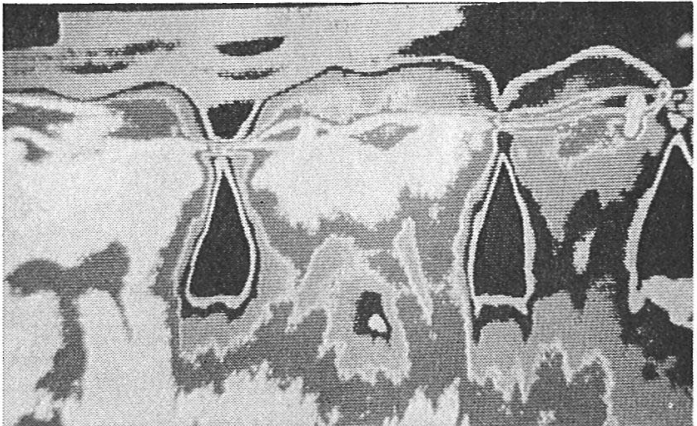

図 11 図 10 (固定後 3 カ月) のカラーデ ーターシステムによる評価

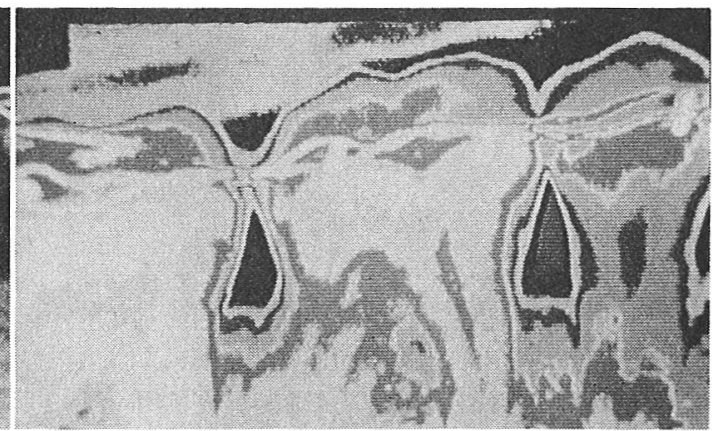

図 13 図 12 (固定後 6 カ月) のカラー データーシステムによる評価 


\section{IV. 考察}

進行した歯周炎の治療法としてプラークコントロール や種々の歯周外科処置などがあるが，特に外傷性咬合歯 を認める症例に，歯肉剝離搔爬手術など歯周外科処置を 行う前後に，歯牙の固定は歯周疾患治療後の予後を左右 する重要な処置法である。

固定を行う事によって歯周組織の炎症の消退や修復治 療の起りやすい環境をつくり, 歯周組織の安静と保定を はかることができる。

それゆえに歯牙を長期保存する上で固定法は意義深い ことである。

歯牙を固定する研究 1 4) は古くより行われ，歯周疾 患 の病因の解明や材料の改良, 進歩に伴って現在までに固 定に関する研究 ${ }^{5,6)}$ は, 多くの研究者によって行われて きた。

固定法には種々の分類法があるが，適用期間により暫 間固定法と永久固定法に分類することができる。

本研究では，歯周疾患の術後において重要な役割を果 たしている暫間固定法のうち内式暫間固定法，すなわち 改良 A-splint 法について検討を行った。

A-splint 法は, 1951 年 ${ }^{8}$ に Obin とArvins により考 案されて以来, 現在広く使用されている固定法の 1 つで あり主として審美性と保持力の面から前歯部に適応され ている報告7 99が多いが， 臼歯部に用いた報告 ${ }^{5,6,10)}$ は少 ないと思われる。

そこで, 今回, 我々は A-splint を改良して充填材と して金属と接着する KG (81-06) レジンを用い，固定部 位は上下滪臼歯部に，症例数は 7 症例，経過観察期間は 固定後 6 カ月とし，この固定法（改良 A-splint 法）に ついて, 臨床的あるいは規格X線写真により評価を行っ た。

固定法では充填材の接着力が装置の推持, 脱離, 二次 カリエスなどの点で特に重要になってくる。そこで以下 の川原 ${ }^{11}$ 等の KG (81-06) レジンの持性に関する報告に 基づき本研究に充媜材としてこの KG (81-06) レジンを 用いた。

(1) 歯科用アマルガム適応範囲を十分満たす材料であ る。

(2) 生物学的に細胞毒性, 組織刺激性が緩慢で市販の コンポジットレジンとほとんど同程度である。

(3) 歯質との接着性が優れているため, 充填物一歯牙 界面の微少漏洩が，ほとんどみられない。

(4) 機械的強度, 特に耐磨耗性が優れているため芷
部修復材料として十分使用できる。

臨床検查用紙，表 3 を用いての経過観察結果は固定後 1 力月に 1 症例, 3 力月に 2 症例, 辺縁破折が, みられ たのみで他には異常はなく良好であった。辺縁破折の原 因としては窩洞形成の不備，充媜不備，咬合調整などの 不備が考えられる。

特に臨床検查項目で注目したいことは，歯間空隙への プラークの畜積による歯肉の炎症, 二次カリエス, 装置 の脱離などがみられなかったことである。このことはプ ラークコントロールの徹底化によることと, KG (81-06) レジンの接着力, 辺縁封鎖性, 機械的強度が良好であっ た事などが理由として考えられる。

次に暫間固定後の歯槽骨の経時的変化（骨の remodeling 効果) については, 規格X線写真とカラーデータ ーシステムを用いて客観的評価を行った。

歯周疾患の治療経過やその他の歯科治療後の経過を X 線写真によって経時的にとらえる研究は現在まで数多 く12_17)行われている。

又, 歯周病領域で $X$ 線写真により歯槽骨の変化を評価 する方法には (1) 特殊なスケール18 21)を用いる方法 (一 次元的評価方法)，(2) 歯槽骨頂の高さ $6,17,22)$ を測定する 方法。(3) 歯槽骨頂部の面積変化を測定する 方 法 ${ }^{15}$ （二 次元的方法)。などがあるが，我々は (1) の Schei-waerhaug の方法を改良したスケールを用いて規格X線写真 上での臼歯部の近心歯間歯槽骨 $(M)$, 遠心歯間部歯槽骨 (D)，根分岐部歯槽骨 (F)，の高さについて測定した。

測定方法は，図 $6 \mathrm{a} ， \mathrm{~b} ， に$ 示し，測定結果については 表 4, 5, 図 7，に示してある。

このスケールを用いて固定前, 固 定後 1 力月, 3 力 月, 6 カ月について，それぞれ測定した結果， 7 症例 中， 1 症例を除き骨の remodeling を認めた。 1 症例に ついて骨の吸収を認めた原因としては充填後の咬合調整 の不備によるものと考えられる。

現在まで歯槽骨の骨の経時的変化に関する研究は歯石 除去 ${ }^{12,17)}$ や歯周外科処置後に関する報告 ${ }^{13 ~ 16) ~}$ はあるが, 暫間固定法による歯槽骨の経時的変化にする報告6) は少 ない。

本研究において, 我々は規格X線写真を用いての固定 後 6 力月間の経過観察結果から，骨の remodeling を認 めたが，さらに骨の remodling に関してより客観的に 評価する為に松江 ${ }^{23}$ 等が報告している NAC 社製 の Color Data system model を用いて規格X線写真をパタ ーン化して，濃度の分布の解析を行った。この方法によ り骨の remodeling は，より客観的に評価できた（図 8〜 
図 13)。

以上，本研究結果を総合的に考えると，暫間固定法を 行う上で最も重要なことは,

(1) 固定を行う前に歯周疾患の原因因子をできる限り 除いておくことと，固定の持つ短所を最小におさえるこ とである。さらに固定装置装着後はプラークコントロー ルの徹底化を十分に行うことである。（患者に対しての モチベーションをも含めて)

(2) レジン充填後, 固定期間中においては, 臨床検査 項目の他に, 咬合状態, 動摇度, 歯周ポケットなどの診 查を定期的に行い, そのつど歯周組織の状態に注意し， 異常があれば, 再度, 修理, 調整を行うことである。

今回は， 7 症例で期間も 6 力月間の結果について報告 したが, 現在, 症例数を増やしワイスマン等の方法など をとりいれて研究を行っている。

\section{V. 結 論}

我が歯科病院に来院した歯周疾患患者の中から特に歯 周外科処置後に暫間固定を必要とした症例， 7 症例につ いて上下颚臼歯部に，KG（81-06）レジンを用い臨床検 查用紙や規格 $\mathrm{X}$ 線写真などから固定前, 固定後 1 力月, 3 力月, 6 力月の観察結果を行い次のような結論を得 た。

1. 金属と接着するレジンは暫間固定材として用いた 場合, 固定前, 固定後 1 力月, 3 力月, 6 力月でも使用 に耐えうる材料である。

2. 暫間固定効果として, 歯間部, 根分岐部の歯槽骨 の骨の remodeling が認められた。

\section{文献}

1) Cassotti, L. : Vetulonian-Etruscan dentistry., Riv. Ita. Stomat., $12: 97-112,1957$.

2) Ward, H.L. and Weinberg, L.A. : An evaluation of periodontal splinting., J.A.M.A., $63: 48-54$, 1961.

3) Goldman, H.M. and Cohen, D.W. : Periodontal therapy., 3 rd ed. C.V. Mosby Co., St. Louis, 642-661, 1964.

4) Prichard, J.F. : Advanced periodontal disease., W.B. Saunders Co., Philadelphia and London, 416-435, 1966.

5）加藤 潶：歯周疾患の固定法，日本 歯科評論，
No. $416: 73-85$, 1977. No. $417: 40-58,1977$.

6) 鴨井久一: 歯周疾患の処置における暫間固定法, 国際歯科ジャーナル, $2(4): 351-361,1975$.

7) Berliner, A. : Ligatures, splints bite planes and pyramids., J.B. Lippincott Co., Philadelphia, 102-121, 1964.

8) Obin, J.N. and Arvins, A.N. : The use of selfcuring resin splints for the temporary stabilization of mobile teeth due to periodontal involvement., J.A.D.A., $42: 320-321,1951$.

9) Coslet, J.G. : Continuing dental education; the incisal edge splint and other methods of temporary stabilization of periodontally involved teeth, no. 3. Ouintessence Pub. Co., Chicago, 1980.

10）加藤 㜯：歯周疾患䍜患歯の固定法, 歯科時報, 29 (5) : 12-19, 1975.

11）川原春幸, 今西嘉次, 武田昭二, 大島 浩, 牧田 輝夫, 工藤象三, 船越 隆: 新コンポジットレジ ン TMM (M)- $\mathrm{SI}_{3} \mathrm{~N}_{4}$-特に脱アマルガム材料とし て, 歯界展望, $58(2): 359-370,1981$.

12）清水飲也, 松江一郎, 加藤安宏, 並木量義 : 歯石 除去の研究 (5), 日歯周誌, $14: 85-86,1972$.

13) Patur, B. and Glickman, I. : Clinical and roentogenographic evaluation of the post treatment healing of infrabony pockets., J. Periodont., $33:$ 164-171, 1962.

14) Matsue, I., Collings, L.C., Zimmarman, R.E. and Vail, C.W. : Microdensitometric analysis of human autogenous alveolar bone implants., J. Periodont., 41 : 489-495, 1970.

15) Plotnick, I.J., Beresin, V.E. and Simkins, A. B. : A technique for standardized serial dental rediographs., J. Periodont., 42 : 297-299, 1971.

16）川崎 仁：口内法による個体 $X$ 線規格撮影とその 歯周疾患への応用, 口病誌, $34: 164-180,1967$.

17）川崎 仁：辺縁性歯周炎に対する口腔清掃および 歯石除去後の歯槽骨頂部の変化, 歯界展望, 39 : 1093-1105, 1972.

18) Schei, O., Waerhaug, J., Lovdal, A. and Arno, A. : Alveolar bone loss as related to oral hygiene and age., J. Periodont., $30: 7-16,1959$.

19) Björn, H. and Holmberg, K. : Radiographic determination of periodontal bone destruction 
in epidemiological research., Odontologic Review, 17 : 232-250, 1966.

20) Bassiouny, M.A. and Grant, A.A. : The accuracy of the schei ruler; a laboratory investigation., J. Periodont., 46 : 748-751, 1975.

21) Kelly, G.P., Cain, R.J., Knowles, J.W., Nissle, R.R., Burgett, F.G., Shick, R.A. and Ramfjord, S.P. : Radiographs in clinical periodontal tri- als., J. Periodont., 46 : 381-386, 1975.

22) Boyle, D.W., Via, W.F. and McFall, W.T. : Radiographic analysis of alveolar crest height and age., J. Periodont., 46 : 236-243, 1973.

23）松江一郎, 清水飲也, 加藤安宏, 増田良男 : 歯周 外科手術の自動解析のアプローチ, 日歯周誌, 15 (1) : 48-54, 1973. 